\title{
SUPERVISI EDUKATIF KOLABORATIF SECARA PERIODIK SEBAGAI UPAYA PENINGKATAN KINERJA GURU DALAM PEMBELAJARAN
}

\author{
Wahyudiono Jokomarsono \\ SMK Negeri 1 Kademangan \\ E-mail: wahyujokomarsono@gmail.com
}

\begin{abstract}
Abstrak: Salah satu peranan kepala sekolah untuk meningkatkan kinerja guru, dapat dilakukan dengan pelaksanaan supervisi. Pendekatan kolaboratif, dimana kepala sekolah sebagai supervisor bersama dengan guru bersepakat untuk menetapkan struktur, proses, dan kriteria untuk menyelesaikan permasalahan yang dihadapi oleh guru. Penerapan kemampuan kepala sekolah dalam pelaksanaan supervisi kolaboratif secara periodik dapat meningkatkan kinerja guru dalam: 1) mengembangkan perangkat pembelajaran, 2) melaksanakan pembelajaran, 3) melaksanakan penilaian hasil belajar peserta didik, 4) melaksanakan tindak lanjut hasil penilaian. Melalui supervisi edukatif kolaboratif yang dilakukan secara periodik untuk meningkatkan kinerja guru, turut meningkatkan kualitas pembelajaran yang berpengaruh pada hasil belajar peserta didik yang juga meningkat, dan terjalin hubungan yang kooperatif dan kolegial antara kepala sekolah dan guru pada satuan pendidikan yang dipimpin.
\end{abstract}

Kata kunci: supervisi; kolaboratif; kinerja guru

\begin{abstract}
One of the principal roles to improve teacher performance, can be done by the implementation of supervision. A collaborative approach, where the headmaster as a supervisor together with the teacher agreed to establish the structure, process, and criteria to solve the problems faced by the teacher. Application of the headmaster's ability in the implementation of periodic collaborative supervision can improve teachers ' performance in: 1) Develop learning devices, 2) conduct learning, 3) carry out the assessment of student learning outcomes Students, 4) carry out the follow-up assessment results. Through the collaborative educative supervision that is done periodically to improve the performance of the teacher, also improve the quality of learning that influence on the outcomes of learners who also increase, and intertwined cooperative relationships and Collegial between the headmaster and the teacher in a led education unit.
\end{abstract}

Keywords: supervision, collaborative, teachers performance

Dalam pembelajaran, seorang guru sebagai pendidik dituntut untuk mampu menerjemahkan nilai-nilai dan kompetensi yang terdapat di dalam kurikulum secara optimal. Walaupun sistem pembelajaran saat ini lebih mengutamakan student centre (pembelajaran berpusat pada siswa) dan bukan lagi teacher centre (pembelajaran berpusat pada guru), namun seorang guru tetap memegang peranan yangsangat pentig dalam membimbing siswa. Bahkan pada era pembelajaran digital saat ini, seorang guru harus memiliki kemampuan yang memadai baik di bidang akademik maupun pedagogik dengan memanfaatkan teknologi yang berkembang untuk mendesain pembelajaran yang kreatif yang memampukan siswa untuk aktif dan dapat berpikir kreatif. Untuk mencapai kompetensi tersebut, seorang guru dituntut harus selalu berinovasi dan meningkatkan kemampuannya baik secara akademik maupun pedagogik. Namun dari semua itu keepala sekolah juga sangat berperan dalam peningkatan potensi guru. Sebagaimana yang diungkapkan oleh Lynne "Principal leadership is the key to successful implementation of mandated, highaccountability, teacher evaluation systems" (Lynne \& John, 2015). Selain itu sekolah sebagai lembaga pendidikan juga memiliki peran penting dalam membentuk seorang guru untuk mencapai tiga kompetensi tersebut. Sebagaimana yang diungkapkan Jaffer "Improvements in educational quality 
will require a balance among three factors: the availability of relevant and adequate physical, human, and financial resources; effective and empowered leadership; and functional monitoring, evaluation, and professional support for school" (Jaffer, 2010). Peranan kepala sekolah dapat diwujudkan melalui pembinaan terhadap guru, mendorong guru untuk mengikuti diklat, workshop, Musyawarah Guru Mata Pelajaran (MGMP), Penilaian Kinerja Guru (PKG), diskusi, dan supervisi edukatif. "In regards to developmental supervision, principals indicated that novice teachers received much more supervision than veteran teachers." (Range, Scherz, Holt, \& Young, 2011).

Sebagai kepala SMK Negeri 1 Kademangan, kepala sekolah merasa perlu melakukan pembinaan dalam meningkatkan kompetensi dan kualitas guru, berdasarkan kondisi yang ditemui melalui hasil diskusi maupun pengamatan, dimana kurang atau rendahnya kinerja dan wawasan guru diakibatkan karena (1) rendahnya kesadaran guru untuk belajar dan meningkatkan kemampuan dan wawasan terhadap perkembangan ilmu pengetahuan yang ada, (2) kurangnya kesempatan guru untuk mengikuti pelatihan baik tingkat daerah, nasional maupun regional, (3) kurang efektifnya pelaksanaan PKG, dan (4) supervisi guru maupun supervisi pendidikan yang bertujuan untuk memperbaiki proses pembelajaran cenderung menitikberatkan pada aspek administrasi. "School leaders need resources to build capacity, particularly in accommodating the new time demands of teacher evaluation" (Lavigne \& Chamberlain, 2017). Menurut Mulkeen "Teacher professional development remains one of the key elements used by education officials to ensure the adequate preparation of teachers for the teaching profession" (Kalule \& Bouchamma, 2014).

Pelaksanaan supervisi edukatif kolaboratif secaara periodik dengan tujuan untuk meningkatkan kinerja guru dalam: 1) mengembangkan perangkat pembelajaran, 2) pelaksanaan pembelajaran, 3) melaksanakan penilaian hasil belajar peserta didik, 4) melaksanakan tindak lanjut hasil penilaian. "Supervision of student teachers in their classroom field experiences as a coherent, theorized process" (Liu, Miller, Dickmann, \& Monday, 2018).

Penetapan Undang Undang Sistem Pendidikan Nomor 20 Tahun 2003 menegaskan bahwa seseorang yang bekerja di dunia pendidikan baik formal, non formal, maupun informal harus mempunya kemampuan khusus di bidang kependidikan itu. Secara umum guru atau pendidik tersebut harus memiliki kompetensi sesuai bidangnya.

Secara spesifik, kompetensi merupakan kemampuan, ketrampilan dan sikap yang dimiliki seseorang serta penerapannya di dalam pekerjaan, sesuai dengan standar kinerja yang dibutuhkan oleh lapangan kerja (Dirjen Dikdasmen, 2004:4). Kompetensi dapat diartikan kewenangan dan kecakapan atau kemampuan seseorang dalam melaksanakan tugas atau pekerjaan dengan jabatan yang disandangnya. Pekerjaan yang dimaksud adalah profesi guru. Rumusan kompetensi guru yang dikembangkan di Indonesia telah tertuang dalam Undang Undang Nomor 14 Tahun 2005 Tentang Guru dan Dosen Pasal 10 Ayat 1 kompetensi guru meliputi kompetensi pedagogik, kompetensi kepribadian, kompetensi sosial, dan kompetensi profesional yang diperoleh melalui pendidikan profesi.

Pada hakikatnya kinerja guru merupakan perilaku seorang guru dalam melaksanakan tugasnya sebagai pendidik dan pengajar ketika mengajar di depan kelas, sesuai dengan kriteria tertentu seperti perencanaan program pembelajaran, pelaksanaan kegiatan proses pembelajaran, dan evaluasi hasil pembelajaran. Pada situasi dan kondisi kerja sehari hari kinerja seorang guru akan nampak dalam aspek kegiatan menjalankan tugas dan cara atau kualitas dalam melaksanakan kegiatan atau tugas tersebut. Sesuai dengan penelitian yang dilakukan oleh Teddlie bahwa "school effectiveness have relevance for studies of teacher effectiveness and ongoing developments in teacher evaluation" (Ellett \& Teddlie, 2003). Berkaitan dengan kinerja guru dalam melaksanakan proses belajar mengajar dan tugas keprofesionalan guru yang tertuang dalam Undang Undang Republik Indonesia Nomor 14 Tahun 2005 Tentang Guru dan Dosen pasal 20 ditegaskan bahwa guru memiliki tugas 
keprofesionalan dalam melaksanakan proses pembelajaran yang bermutu, serta menilai dan mengevaluasi hasil pembelajaran. Kinerja guru memiliki spesifikasi tertentu, kinerja guru dapat dilihat dan diukur berdasarkan spesifikasi atau kriteria kompetensi yang harus dimiliki oleh setiap guru. Berkaitan dengan kinerja guru, maka wujud perilaku yang dimaksud adalah kegiatan guru dalam proses pembelajaran yaitu bagaimana kemampuan seorang guru dalam merencanakan, melaksanakan kegiatan pembelajaran, dan menilai hasil belajar.

Sesuai dengan tugas dan kewenangannya, kepala sekolah perlu melakukan supervisi terhadap guru dan tenaga kependidikan di sekolah tempatnya bertugas. "Educational supervision is any helping activity intended to improve the teaching/learning process" (Bouchamma, 2007). Pelaksanaan supervisi yang dilakukan oleh kepala sekolah terhadap guru dapat berupa wawancara, observasi, maupun berdasarkan portofolio dalam proses belajar mengajar atau dalam kegiatan bimbingan dan konseling guru. Dalam melaksanakan observasi, kepala sekolah dapat memilih satu atau beberapa kelas, serta mengamati kegiatan guru dalam proses belajar mengajar di satu atau beberapa kelas tersebut.

Hipotesa tindakan yang dibuat adalah "Kinerja guru dalam pembelajaran di kelas akan meningkat jika supervisi edukatif kolaboratif dilaksanakan dengan sistematis, proaktif, dan terus menerus".

\section{METODE}

Metode yang digunakan dalam penelitian ini merupakan penelitian tindakan sekolah yang hampir mirip dengan penelitian tindakan kelas, namun dilaksanakan oleh kepala sekolah sebagai kepala sekolah, terhadap proses belajar mengajar guru di dalam kelas. "Supervision is a well-defined term in the interpersonal relationship between thesis supervisors and teachers" (Bazrafkan, Yousefy, Amini, \& Yamani, 2019). Penelitian tindakan sekolah ini direncanakan dalam dua (2) siklus. Tahapan dalam setiap siklus terdiri dari 4 tahap yaitu perencanaan, pelaksanaan, observasi (pengamatan) dan refleksi. Siklus tersebut dapat digambarkan sebagai berikut:

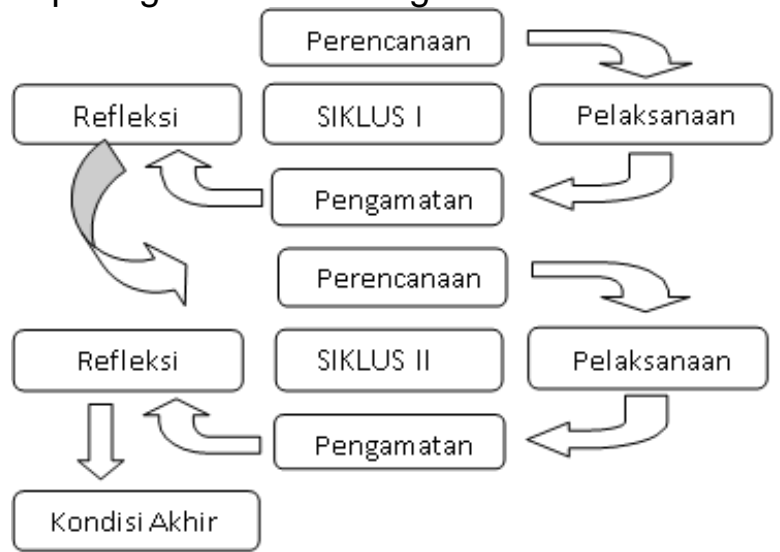

Gambar 1. Langkah-langkah Penelitian Tindakan Kelas

\section{Waktu dan Subyek Penelitian}

Penelitian ini dilaksanakan di SMK Negeri 1 Kademangan Kecamatan Kademangan Kabupaten Blitar pada semester gasal Tahun Pelajaran 2017/2018. Subyek penelitian adalah guru yang merupakan perwakilan dari setiap kelompok Musyawarah Guru Mata Pelajaran (MGMP) yang ada di SMK Negeri 1 Kademangan, sebanyak sembilan belas (19) orang guru.

\section{Teknik Pengumpulan Data}

Teknik pengumpulan data yang digunakan adalah pengamatan, wawancara, dan dokumentasi. Sedangkan alat pengumpul data yang digunakan adalah instrumen supervisi, pedoman supervisi akademik, dan alat dokumentasi (foto, alat rekam, dan lain-lain). Pada penelitian ini, teknik pengumpulan data yang digunakan terdiri atas empat kegiatan pokok yakni pengumpulan data awal, data hasil analisis setiap akhir siklus, serta tanggapam lain dari guru terhadap pelaksanaan supervisi edukatif model kolaboratif.

\section{Teknik Analisis Data}

Data yang telah dikumpulkan dianalisis dengan menggunakan analisis kualitatif dan kuantitatif. Analisis kualitatif digunakan untuk menjelaskan perubahan perilaku guru dalam pembelajaran dan perilaku kepala sekolah dalam melaksanakan supervisi guru. Sedangkan analisis kuantitatif digunakan untuk mengetahui keberhasilan guru dan siswa.

\section{Prosedur Penelitian}


Pelaksanaan penelitian ini dilakukan dalam beberapa siklus, karena penelitian ini merupakan penelitian tindakan. Pelaksanaan penelitian ini dilakukan sebanyak dua (2) siklus. Siklus-siklus ini merupakan rangkaian yang saling berkelanjutan, maksudnya siklus kedua merupakan kelanjutan atau perbaikan dari hasil refleksi yang terdapat pada siklus pertama. Pada setiap siklus terdapat tahap persiapan tindakan, pelaksanaan tindakan, pemantauan dan evaluasi, dan refleksi.

\section{Indikator Keberhasilan}

Dalam penelitian tindakan ini, indikator keberhasilan yang dicapai oleh kepala sekolah adalah apabila presentase rata-rata keberhasilan dari guru yang disupervisi meningkat. Sedangkan tolak ukur nilai keberhasilan dari seorang guru lebih besar atau sama dengan $(\geq) 75$. Aspek-aspek kinerja guru yang digunakan sebagai indikator keberhasilan, diantaranya: kinerja guru dalam mengembangkan dan menyusun Rencana Proses Pembelajaran (RPP), kinerja guru dalam melaksanakan pembelajaran, kinerja guru dalam melakukan penilaian hasil belajar peserta didik, dan kinerja guru dalam melaksanakan tindak lanjut hasil penilaian hasil belajar peserta didik. Dengan meningkatnya kinerja guru maka dapat berakibat terjadinya pembelajaran efektif yang mampu memberikan motivasi belajar pada peserta didik dengan meningkatnya hasil belajar terutama nilai ujian semester.

\section{HASIL}

Berdasarkan pemantauan yang dilakukan selama persiapan, pelaksanaan, dan tindak lanjut dalam penelitian tindakan ini, diperoleh berbagai data baik dari guru yang sedang melaksanakan proses belajar mengajar, peserta didik yang belajar, maupun kepala sekolah yang sedang melaksanakan supervisi. Gambaran yang merupakan hasil penelitian dan temuan adalah sebagai berikut: (1) Perencanaan. Kepala sekolah bersama guru membuat perencanaan yang berkaitan dengan pembuatan instrumen penelitian. Instrumen penelitian tersebut dibuat dengan mengacu pada indikator yang terdapat pada Panduan Supervisi Akademik Direktur Jendral Pendidikan Dasar dan Menengah (Dirjen Dikdasmen); (2) Pengamatan. Instrumen penelitian yang digunakan berupa instrumen yang sesuai dengan indikator yang terdapat pada Panduan Supervisi Akademik Dirjen Dikdasmen; (3) Tindakan. Tindakan yang dilakukan oleh kepala sekolah pada pelaksanaan supervisi adalah: (a) Kepala sekolah memberikan indikator yang harus dicapai oleh seorang guru pada saat persiapan, pelaksanaan, dan penilaian paling lambat satu minggu sebelum pelaksanaan supervisi; (b) Kepala sekolah meminta guru untuk mengisi format penilaian supervisi yang telah disediakan dengan jujur sesuai keadaan yang ada dan kemampuan yang dimiliki; (c) Kepala sekolah melakukan observasi pembelajaran oleh guru di dalam kelas secara langsung; dan (4) Refleksi. Berdasarkan data yang diperoleh dari hasil pengamatan dan tindakan, kepala sekolah melakukan analisis dan evaluasi untuk mengetahui hasil yang dicapai sudah memenuhi tujuan yang diinginkan atau belum.

\section{Siklus I}

Hasil pelaksanaan penelitian tindakan pada siklus I ini dapat dilihat pada tabel-tabel berikut:

Tabel 1. Data Hasil Supervisi Perencanaan Pembelajaran

\begin{tabular}{|c|c|c|c|}
\hline No & Indikator & $\begin{array}{c}\sum \text { Guru } \\
\text { Berhasil } \\
\text { (Skor } \geq 75)\end{array}$ & $\begin{array}{c}\% \\
\text { Keber- } \\
\text { hasilan }\end{array}$ \\
\hline 1 & $\begin{array}{l}\text { Merumuskan } \\
\text { indikator pencapaian } \\
\text { kompetensi }\end{array}$ & 15 & 78,95 \\
\hline 2 & $\begin{array}{l}\text { Mendeskripsikan } \\
\text { tujuan pembelajaran }\end{array}$ & 15 & 78,95 \\
\hline 3 & $\begin{array}{l}\text { Menentukan materi } \\
\text { sesuai dengan } \\
\text { kompetensi yang } \\
\text { telah ditentukan }\end{array}$ & 14 & 73,68 \\
\hline 4 & $\begin{array}{l}\text { Mengorganisasikan } \\
\text { materi berdasarkan } \\
\text { urutan dan } \\
\text { kelompok }\end{array}$ & 19 & 100 \\
\hline 5 & $\begin{array}{l}\text { Mengalokasikan } \\
\text { waktu }\end{array}$ & 9 & 47,36 \\
\hline 6 & $\begin{array}{l}\text { Menentukan model } \\
\text { pembelajaran yang } \\
\text { sesuai }\end{array}$ & 10 & 52,63 \\
\hline 7 & $\begin{array}{l}\text { Merancang prosedur } \\
\text { pembelajaran }\end{array}$ & 10 & 52,63 \\
\hline 8 & $\begin{array}{l}\text { Menentukan media } \\
\text { pembelajaran atau } \\
\text { peralatan dan bahan } \\
\text { praktikum yang akan } \\
\text { digunakan }\end{array}$ & 16 & 84,21 \\
\hline 9 & $\begin{array}{l}\text { Menentukan sumber } \\
\text { belajar yang sesuai } \\
\text { (berupa buku materi } \\
\text { ajar, modul, progam } \\
\text { komputer dan } \\
\text { sejenisnya) }\end{array}$ & 9 & 47,36 \\
\hline
\end{tabular}




\begin{tabular}{|c|c|c|c|}
\hline 10 & $\begin{array}{l}\text { Menentukan teknik } \\
\text { penilaian }\end{array}$ & 14 & 73,68 \\
\hline & Rata-rata Keberh & & $68,42 \%$ \\
\hline
\end{tabular}

Tabel 2. Data Hasil Supervisi Pelaksanaan Pembelajaran

\begin{tabular}{|c|c|c|c|}
\hline No & Indikator & $\begin{array}{c}\sum \text { Guru } \\
\text { Berhasil } \\
\text { (Skor } \geq 75)\end{array}$ & $\begin{array}{c}\% \\
\text { Keber- } \\
\text { hasilan }\end{array}$ \\
\hline 1 & Membuka pelajaran & 16 & 84,21 \\
\hline 2 & $\begin{array}{l}\text { Melakukan } \\
\text { apersepsi dan } \\
\text { memberi motivasi } \\
\text { kepada peserta } \\
\text { didik. }\end{array}$ & 13 & 68,42 \\
\hline 3 & $\begin{array}{l}\text { Menyajikan materi } \\
\text { ajar sesuai dengan } \\
\text { kompetensi dasar } \\
\text { dan indikator } \\
\text { pencapaian } \\
\text { kompetensi }\end{array}$ & 13 & 68,42 \\
\hline 4 & $\begin{array}{l}\text { Menerapkan model } \\
\text { pembelajaran } \\
\text { sesuai dengan } \\
\text { model } \\
\text { pembelajaran yang } \\
\text { telah ditentukan } \\
\text { dalam RPP }\end{array}$ & 16 & 84,21 \\
\hline 5 & $\begin{array}{l}\text { Melaksanakan } \\
\text { pembelajaran } \\
\text { sesuai dengan } \\
\text { langkah-langkah } \\
\text { pembelajaran yang } \\
\text { benar dan tertuang } \\
\text { dalam RPP }\end{array}$ & 12 & 63,15 \\
\hline 6 & $\begin{array}{l}\text { Mengatur kegiatan } \\
\text { peserta didik di } \\
\text { kelas sesuai } \\
\text { dengan tahapan- } \\
\text { tahapan } \\
\text { pembelajaran yang } \\
\text { tertuang dalam } \\
\text { RPP }\end{array}$ & 13 & 68,42 \\
\hline 7 & $\begin{array}{l}\text { Menggunakan } \\
\text { media } \\
\text { pembelajaran yang } \\
\text { dikembangkan } \\
\text { sendiri sesuai } \\
\text { dengan materi ajar } \\
\text { dan tertuang di } \\
\text { dalam RPP }\end{array}$ & 16 & 84,21 \\
\hline 8 & $\begin{array}{l}\text { Menggunakan } \\
\text { sumber belajar } \\
\text { yang telah dipilih } \\
\text { dan tertuang dalam } \\
\text { RPP }\end{array}$ & 16 & 84,21 \\
\hline 9 & $\begin{array}{l}\text { Melakukan interaksi } \\
\text { dengan peserta } \\
\text { didik menggunakan } \\
\text { bahasa yang } \\
\text { komunikatif }\end{array}$ & 12 & 63,15 \\
\hline 10 & $\begin{array}{l}\text { Memberikan } \\
\text { pertanyaan dan }\end{array}$ & 12 & 63,15 \\
\hline
\end{tabular}

\begin{tabular}{|c|c|c|c|}
\hline & $\begin{array}{l}\text { umpan balik, untuk } \\
\text { mengetahui dan } \\
\text { memperkuat } \\
\text { pemahaman } \\
\text { peserta didik } \\
\text { terhadap materi } \\
\text { ajar selama proses } \\
\text { belajar mengajar }\end{array}$ & & \\
\hline 11 & $\begin{array}{l}\text { Bersama peserta } \\
\text { didik menyimpulkan } \\
\text { pembelajaran }\end{array}$ & 12 & 63,15 \\
\hline 12 & $\begin{array}{l}\text { Menggunakan } \\
\text { waktu secara efektif } \\
\text { dan efisien }\end{array}$ & 12 & 63,15 \\
\hline \multicolumn{3}{|c|}{ Rata-rata Keberhasilan } & $72,25 \%$ \\
\hline
\end{tabular}

Tabel 3. Data Hasil Supervisi Penilaian Hasil Belajar Peserta Didik

\begin{tabular}{|c|c|c|c|}
\hline No & Indikator & $\begin{array}{c}\text { ¿Guru } \\
\text { Berhasil } \\
\text { (Skor } \geq 75)\end{array}$ & $\begin{array}{c}\% \\
\text { Keber- } \\
\text { hasilan }\end{array}$ \\
\hline 1 & $\begin{array}{l}\text { Menyusun instrumen } \\
\text { penilaian sesuai } \\
\text { dengan kompetensi } \\
\text { dasar }\end{array}$ & 16 & 84,21 \\
\hline 2 & $\begin{array}{l}\text { Melaksanakan } \\
\text { kegiatan penilaian } \\
\text { hasil belajar }\end{array}$ & 16 & 84,21 \\
\hline 3 & Memeriksa hasil tes & 13 & 68,42 \\
\hline 4 & $\begin{array}{l}\text { Mengolah hasil } \\
\text { penilaian }\end{array}$ & 19 & 100 \\
\hline 5 & $\begin{array}{l}\text { Menganalisis hasil } \\
\text { penilaian } \\
\text { berdasarkan tingkat } \\
\text { kesukaran, daya } \\
\text { pembeda, validitas, } \\
\text { dan reabilitas }\end{array}$ & 13 & 68,42 \\
\hline 6 & $\begin{array}{l}\text { Menyimpulkan hasil } \\
\text { penilaian secara } \\
\text { jelas dan logis }\end{array}$ & 13 & 68,42 \\
\hline 7 & $\begin{array}{l}\text { Menyusun laporan } \\
\text { hasil penilaian }\end{array}$ & 13 & 68,42 \\
\hline 8 & $\begin{array}{l}\text { Memperbaiki } \\
\text { perangkat penilaian }\end{array}$ & 19 & 100 \\
\hline \multicolumn{3}{|c|}{ Rata-rata Keberhasilan } & $82,46 \%$ \\
\hline
\end{tabular}

Tabel 4. Data Hasil Supervisi Pelaksanaan Tindak Lanjut Hasil Penilaian

\begin{tabular}{clcc}
\hline No & \multicolumn{1}{c}{ Indikator } & $\begin{array}{c}\sum \text { Guru } \\
\text { Berhasil } \\
\text { (Skor } \geq 75)\end{array}$ & $\begin{array}{c}\% \\
\text { Keber- } \\
\text { hasilan }\end{array}$ \\
\hline 1 & $\begin{array}{l}\text { Mengidentifikasi } \\
\text { kebutuhan tindak } \\
\text { lanjut hasil penilaian }\end{array}$ & 13 & 68,42 \\
\hline 2 & $\begin{array}{l}\text { Menyusun program } \\
\text { tindak lanjut hasil } \\
\text { penilaian }\end{array}$ & 16 & 84,21 \\
\hline 3 & Melaksanakan & 9 & 47,36 \\
\hline
\end{tabular}


Wahyudiono Jokomarsono, Supervisi Edukatif Kolaboratif Secara Periodik Sebagai Upaya Peningkatan Kinerja Guru Dalam Pembelajaran 47

\begin{tabular}{|c|c|c|c|}
\hline & tindak lanjut & & \\
\hline 4 & $\begin{array}{l}\text { Melakukan evaluasi } \\
\text { program tindak } \\
\text { lanjut hasil penilaian }\end{array}$ & 9 & 47,36 \\
\hline 5 & $\begin{array}{l}\text { Menganalisis hasil } \\
\text { evaluasi program } \\
\text { tindak lanjut hasil } \\
\text { penilaian }\end{array}$ & 9 & 47,36 \\
\hline & Rata-rata Keberhasilan & & $58,94 \%$ \\
\hline
\end{tabular}

\begin{tabular}{|c|c|c|c|}
\hline & $\begin{array}{l}\text { peralatan dan bahan } \\
\text { praktikum yang akan } \\
\text { digunakan }\end{array}$ & & \\
\hline 9 & $\begin{array}{l}\text { Menentukan sumber } \\
\text { belajar yang sesuai } \\
\text { (berupa buku materi } \\
\text { ajar, modul, progam } \\
\text { komputer dan } \\
\text { sejenisnya) }\end{array}$ & 18 & 94,73 \\
\hline 10 & $\begin{array}{l}\text { Menentukan teknik } \\
\text { penilaian }\end{array}$ & 16 & 84,21 \\
\hline \multicolumn{3}{|c|}{ Rata-rata Keberhasilan } & $92,63 \%$ \\
\hline
\end{tabular}

Grafik 1. Persentase Keberhasilan Siklus I Persentase Keberhasilan Siklus I

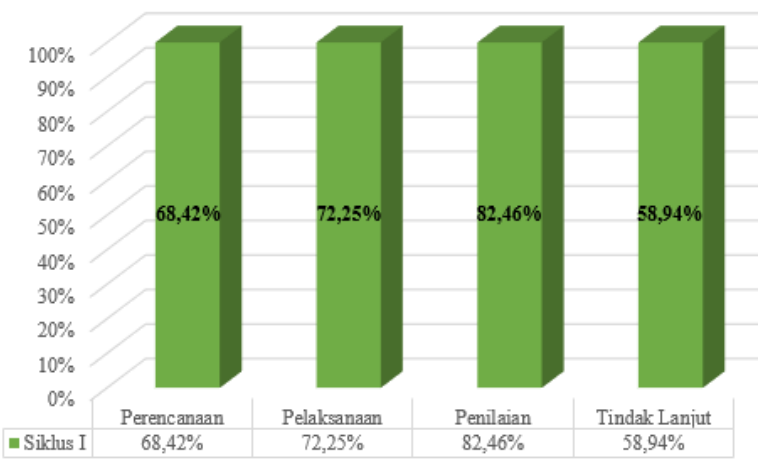

\section{Siklus II}

Hasil pelaksanaan penelitian tindakan pada siklus II ini dapat dilihat pada tabel-tabel berikut:

Tabel 5. Data Hasil Supervisi Perencanaan Pembelajaran

\begin{tabular}{|c|c|c|c|}
\hline No & Indikator & $\begin{array}{c}\sum \text { Guru } \\
\text { Berhasil } \\
\text { (Skor } \geq 75)\end{array}$ & $\begin{array}{c}\% \\
\text { Keber- } \\
\text { hasilan }\end{array}$ \\
\hline 1 & $\begin{array}{l}\text { Merumuskan } \\
\text { indikator pencapaian } \\
\text { kompetensi }\end{array}$ & 18 & 94,73 \\
\hline 2 & $\begin{array}{l}\text { Mendeskripsikan } \\
\text { tujuan pembelajaran }\end{array}$ & 18 & 94,73 \\
\hline 3 & $\begin{array}{l}\text { Menentukan materi } \\
\text { sesuai dengan } \\
\text { kompetensi yang } \\
\text { telah ditentukan }\end{array}$ & 18 & 94,73 \\
\hline 4 & $\begin{array}{l}\text { Mengorganisasikan } \\
\text { materi berdasarkan } \\
\text { urutan dan } \\
\text { kelompok }\end{array}$ & 16 & 84,21 \\
\hline 5 & $\begin{array}{l}\text { Mengalokasikan } \\
\text { waktu }\end{array}$ & 19 & 100 \\
\hline 6 & $\begin{array}{l}\text { Menentukan model } \\
\text { pembelajaran yang } \\
\text { sesuai }\end{array}$ & 18 & 94,73 \\
\hline 7 & $\begin{array}{l}\text { Merancang prosedur } \\
\text { pembelajaran }\end{array}$ & 16 & 84,21 \\
\hline 8 & $\begin{array}{l}\text { Menentukan media } \\
\text { pembelajaran atau }\end{array}$ & 19 & 100 \\
\hline
\end{tabular}

Tabel 6. Data Hasil Supervisi Pelaksanaan Pembelajaran

\begin{tabular}{|c|c|c|c|}
\hline No & Indikator & $\begin{array}{c}\sum \text { Guru } \\
\text { Berhasil } \\
\text { (Skor } \geq 75)\end{array}$ & $\begin{array}{c}\% \\
\text { Keber- } \\
\text { hasilan }\end{array}$ \\
\hline 1 & Membuka pelajaran & 19 & 100 \\
\hline 2 & $\begin{array}{l}\text { Melakukan } \\
\text { apersepsi dan } \\
\text { memberi motivasi } \\
\text { kepada peserta } \\
\text { didik. }\end{array}$ & 18 & 94,73 \\
\hline 3 & $\begin{array}{l}\text { Menyajikan materi } \\
\text { ajar sesuai dengan } \\
\text { kompetensi dasar } \\
\text { dan indikator } \\
\text { pencapaian } \\
\text { kompetensi }\end{array}$ & 17 & 89,47 \\
\hline 4 & $\begin{array}{l}\text { Menerapkan model } \\
\text { pembelajaran } \\
\text { sesuai dengan } \\
\text { model } \\
\text { pembelajaran yang } \\
\text { telah ditentukan } \\
\text { dalam RPP }\end{array}$ & 16 & 84,21 \\
\hline 5 & $\begin{array}{l}\text { Melaksanakan } \\
\text { pembelajaran } \\
\text { sesuai dengan } \\
\text { langkah-langkah } \\
\text { pembelajaran yang } \\
\text { benar dan tertuang } \\
\text { dalam RPP } \\
\end{array}$ & 18 & 94,73 \\
\hline 6 & $\begin{array}{l}\text { Mengatur kegiatan } \\
\text { peserta didik di } \\
\text { kelas sesuai } \\
\text { dengan tahapan- } \\
\text { tahapan } \\
\text { pembelajaran yang } \\
\text { tertuang dalam } \\
\text { RPP }\end{array}$ & 18 & 94,73 \\
\hline 7 & $\begin{array}{l}\text { Menggunakan } \\
\text { media } \\
\text { pembelajaran yang } \\
\text { dikembangkan } \\
\text { sendiri sesuai } \\
\text { dengan materi ajar } \\
\text { dan tertuang di } \\
\text { dalam RPP }\end{array}$ & 16 & 84,21 \\
\hline 8 & $\begin{array}{l}\text { Menggunakan } \\
\text { sumber belajar } \\
\text { yang telah dipilih } \\
\text { dan tertuang dalam }\end{array}$ & 19 & 100 \\
\hline
\end{tabular}




\begin{tabular}{|c|c|c|c|}
\hline & RPP & & \\
\hline 9 & $\begin{array}{l}\text { Melakukan interaksi } \\
\text { dengan peserta } \\
\text { didik menggunakan } \\
\text { bahasa yang } \\
\text { komunikatif }\end{array}$ & 19 & 100 \\
\hline 10 & $\begin{array}{l}\text { Memberikan } \\
\text { pertanyaan dan } \\
\text { umpan balik, untuk } \\
\text { mengetahui dan } \\
\text { memperkuat } \\
\text { pemahaman } \\
\text { peserta didik } \\
\text { terhadap materi } \\
\text { ajar selama proses } \\
\text { belajar mengajar }\end{array}$ & 17 & 89,47 \\
\hline 11 & $\begin{array}{l}\text { Bersama peserta } \\
\text { didik menyimpulkan } \\
\text { pembelajaran }\end{array}$ & 18 & 94,73 \\
\hline 12 & $\begin{array}{l}\text { Menggunakan } \\
\text { waktu secara efektif } \\
\text { dan efisien }\end{array}$ & 19 & 100 \\
\hline \multicolumn{3}{|c|}{ Rata-rata Keberhasilan } & $93,86 \%$ \\
\hline
\end{tabular}

Tabel 7. Data Hasil Supervisi Penilaian Hasil Belajar Peserta Didik

\begin{tabular}{|c|c|c|c|}
\hline No & Indikator & $\begin{array}{c}\sum \text { Guru } \\
\text { Berhasil } \\
\text { (Skor } \geq 75)\end{array}$ & $\begin{array}{c}\% \\
\text { Keber- } \\
\text { hasilan }\end{array}$ \\
\hline 1 & $\begin{array}{l}\text { Menyusun } \\
\text { instrumen penilaian } \\
\text { sesuai dengan } \\
\text { kompetensi dasar }\end{array}$ & 18 & 94,73 \\
\hline 2 & $\begin{array}{l}\text { Melaksanakan } \\
\text { kegiatan penilaian } \\
\text { hasil belajar }\end{array}$ & 18 & 94,73 \\
\hline 3 & Memeriksa hasil tes & 18 & 94,73 \\
\hline 4 & $\begin{array}{l}\text { Mengolah hasil } \\
\text { penilaian }\end{array}$ & 19 & 100 \\
\hline 5 & $\begin{array}{l}\text { Menganalisis hasil } \\
\text { penilaian } \\
\text { berdasarkan tingkat } \\
\text { kesukaran, daya } \\
\text { pembeda, validitas, } \\
\text { dan reabilitas }\end{array}$ & 17 & 89,47 \\
\hline 6 & $\begin{array}{l}\text { Menyimpulkan hasil } \\
\text { penilaian secara } \\
\text { jelas dan logis }\end{array}$ & 17 & 89,47 \\
\hline 7 & $\begin{array}{l}\text { Menyusun laporan } \\
\text { hasil penilaian }\end{array}$ & 19 & 100 \\
\hline 8 & $\begin{array}{l}\text { Memperbaiki } \\
\text { perangkat penilaian }\end{array}$ & 16 & 84,21 \\
\hline \multicolumn{3}{|c|}{ Rata-rata Keberhasilan } & $93,426 \%$ \\
\hline
\end{tabular}

Tabel 8. Data Hasil Supervisi Pelaksanaan Tindak Lanjut Hasil Penilaian

\begin{tabular}{cccc}
\hline No & Indikator & $\begin{array}{c}\sum \text { Guru } \\
\text { Berhasil } \\
\text { (Skor } \geq 75)\end{array}$ & $\begin{array}{c}\% \\
\text { Keber- } \\
\text { hasilan }\end{array}$ \\
\hline 1 & $\begin{array}{l}\text { Mengidentifikasi } \\
\text { kebutuhan tindak } \\
\text { lanjut hasil penilaian }\end{array}$ & 16 & 84,21 \\
\hline
\end{tabular}

\begin{tabular}{clcc}
\hline 2 & $\begin{array}{l}\text { Menyusun program } \\
\text { tindak lanjut hasil } \\
\text { penilaian }\end{array}$ & 16 & 84,21 \\
\hline 3 & $\begin{array}{l}\text { Melaksanakan } \\
\text { tindak lanjut }\end{array}$ & 16 & 84,21 \\
\hline 4 & $\begin{array}{l}\text { Melakukan evaluasi } \\
\text { program tindak } \\
\text { lanjut hasil penilaian }\end{array}$ & 16 & 84,21 \\
\hline 5 & $\begin{array}{l}\text { Menganalisis hasil } \\
\text { evaluasi program } \\
\text { tindak lanjut hasil } \\
\text { penilaian }\end{array}$ & 16 & $\mathbf{8 4 , 2 1}$ \\
\hline & Rata-rata Keberhasilan & $\mathbf{8 4 , 2 1 \%}$ \\
\hline
\end{tabular}

Grafik 2. Persentase Keberhasilan Siklus II Persentase Keberhasilan Siklus II

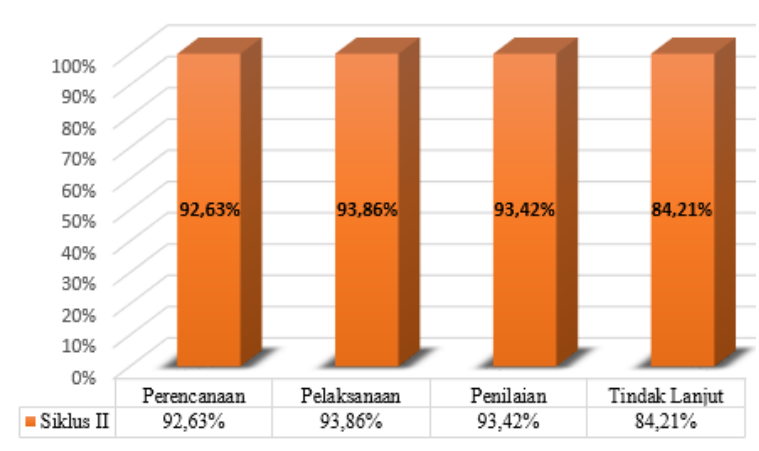

\section{PEMBAHASAN}

\section{Siklus I}

Berdasarkan data yang disajikan pada tabel 1 sampai dengan tabel 4 , dapat dijelaskan sebagai berikut:

a. Perencanaan Pembelajaran Siklus I

Setelah dilaksanakan diskusi dengan guru yang disupervisi dalam penelitian tindakan ini, maka peneliti menulis hasil refleksi perencanaan pembelajaran untuk siklus I sebagai berikut:

1) Mendeskripsikan tujuan pembelajaran , terdapat lima belas (15) guru dengan persentase $78,95 \%$, berdasarkan data tersebut kegiatan guru sudah baik. Kondisi ini perlu dipertahankan untuk 15 guru tersebut, namun ada beberapa guru yang perlu dimotivasi.

2) Menentukan materi yang sesuai dengan kompetensi yang telah ditentukan, terdapat sebanyak 15 guru dengan presentasi $78,95 \%$, berdasarkan data tersebut kegiatan guru perlu 
dipertahankan dan bula perlu ditingkatkan.

3) Mengorganisasikan

materi berdasarkan urutan dan kelompok sebanyak empat belas (14) guru dengan presentasi 73,68\%. Berdasarkan hasil tersebut, dapat dikatakan bahwa hasil yang diperoleh dinilai cukup, namun tentunya guru perlu diberi bimbingan lagi tentang bagaimana mengorganisasikan materi berdasarkan urutan dan kelompok kompetensi dasar yang sesuai. Guru diberi contoh pembelajaran Contextual Teaching Learning(CTL), Cooperative Learning (CL), dan model pembelajaran lain yang sesuai dengan materi yang diberikan.

4) Mengalokasikan waktu, semua guru (sembilan belas guru) dengan presentasi $100 \%$ dapat menentukan alokasi waktu pembelajaran dengan baik sesuai dengan kalender akademik yang digunakan. Kegiatan pada bagian ini perlu dipertahankan yakni dengan meningkatkan kegiatan Musyawarah Guru Mata Pelajaran (MGMP) di sekolah dengan didampingi peneliti.

5) Menentukan model pembelajaran yang sesuai sebanyak sembilan (9) guru dengan presentasi 47,36\%. Berdasarkan nilai tersebut dapat dikatakan bahwa penentuan model pembelajaran yang sesuai masih kurang berhasil. Guru perlu diberi bimbingan, pengarahan dengan cara berdiskusi dengan peneliti untuk menentukan model pembelajaran yang berorientasi pada peserta didik, menarik dan membangun sesuai dengan karakteristik peserta didik dan materi ajar yang diberikan.

6) Merancang prosedur pembelajaran sebanyak sepuluh (10) guru dengan persentase $52,63 \%$. Pada penentuan prosedur sangat berkaitan dengan model pembelajaran yang digunakan, yakni prosedur penerapan sintak-sintak yang perlu dilakukan sesuai dengan model pembelajaran yang dipilih. Masih banyak guru yang terpaku pada prosedur yang konvensional dengan model ceramah, pemberian punishment atau hukuman terhadap peserta didik jika kurang mampu, memperoleh hasil belajar rendah, atau yang melanggar aturan selama pembelajaran.

7) Menentukan media pembelajaran, peralatan dan bahan yang akan digunakan sebanyak 10 guru dengan persentase $52,63 \%$. Sebagian besar guru pada bagian ini masih terfokus pada media pembelajaran instan yang dibeli atau dibuat oleh perusahaan, padahal seorang guru yang profesional dituntut untuk dapat mengembangkan dan membuat media pembelajaran sebagai bentuk peningkatan kompetensi dan daya inovatif guru. Dari data tersebut dapat dikatakan bahwa masih banyak guru yang perlu dimotivasi untuk mengembangkan media pembelajarna yang kreatif dan inovatif sesuai dengan materi ajar.

8) Menentukan sumber belajar yang sesuai sebanyak enam belas (16) guru dengan persentase $84,21 \%$. Bagian ini menunjukkan hasil yang sangat baik, walaupun masih ada beberapa guru yang perlu dimotivasi dan dibimbing untuk dapat menentukan sumber belajar yang tepat sesuai dengan materi ajar yang diberikan.

9) Menentukan teknik penilaian sebanyak 9 guru dengan persentase 47,36\%. Teknik-teknik penilaian yang dibuat oleh guru dalam mengembangkan instrumen penilaian masih kurang beragam dan banyak yang belum sesuai dengan indikator pembelajaran yang sudah ditetapkan sebelumnya. Guru masih terfokus pada teknik penilaian yang berorientasi pada hasil, sementara tuntutan pendidikan saat ini seorang guru perlu melakukan penilaian proses peserta didik. Sehingga proses yang dilakukan oleh peserta didik benar-benar memberikan hasil kerja yang telah mereka lakukan.

b. Pelaksanaan Pembelajaran Siklus I

Hasil refleksi supervisi pelaksanaan pembelajaran setelah diadakan diskusi dengan guru kelas sebagai berikut:

1) Membuka pelajaran dengan metode yang sesuai. Sebagian besar guru sudah mampu membuka pelajaran dengan menggunakan metode yang tepat. Guru yang dianggap mampu membuka pelajaran dengan tepat 
sebanyak 16 guru dengan persentase $84,21 \%$. Berdasarkan persentase tersebut, guru perlu mempertahankan metode yang digunakan selama ini. Namun masih ada 3 guru yang belum sesuai dan perlu diajak diskusi bersama dengan peneliti.

2) Menyajikan materi dalam pembelajaran. Dalam menyajikan materi pelajaran, rata-rata guru sudah melakukan dengan baik, dan berdasarkan pengamatan terdapat 13 guru yang dikategorikan baik. Jika hasil tersebut disajikan dalam bentuk persentase maka sudah mencapai $68,42 \%$. Dalam menyajikan materi ajar, guru perlu melakukan persiapan yang lebih matang, karena dari hasil yang ditemui masih banyak guru yang belum memiliki atau kurang mempersiapkan diri dalam penyajian materi. Sebagian guru dianggap masih kurang menguasai materi yang diberikan, sehingga mengakibatkan peserta didik sulit menerima materi dan kurang memahami tujuan pembelajaran yang diinginkan oleh guru.

3) Menerapkan model dan prosedur pembelajaran yang telah ditentukan berjumlah 13 guru dengan persentase $68,42 \%$. Dalam penggunaan model pembelajaran, guru masih terfokus pada model konvensional berupa ceramah dan pembelajaran berorientasi pada guru (teacher oriented). Guru masih memfungsikan dirinya sebagai sumber belajar utama, dimana hanya sekedar mentransfer ilmu kepada peserta didik. Sebagai perbaikan, guru-guru yang masih belum memahai penggunaan model pembelajaran modern yang berorientasi pada peserta didik (student oriented), diwajibkan mempelajari model-model pembelajaran yang berorientasi pada peserta didik dengan membaca buku-buku, mencari atau membaca referensi dari internet yang berkaitan dengan model-model pembelajaran modern sesuai dengan pendidikan abad 21, seperti model pembelajaran konteksual (Contextual Teaching Learning), model pembelajaran kooperatif (Cooperative Learning), model pembelajaran inkuiri (Inquiry Learning), dan model-model pembelajaran lain yang sesuai. Selain itu peneliti sebagai kepala sekolah dapat memberikan contoh-contoh model pembelajaran modern berupa video atau media lain.

4) Mengatur kegiatan peserta didik di kelas terdapat 15 guru yang melakukannya dengan baik dengan persentase $84,21 \%$. Berdasarkan data tersebut sebagian besar guru sudah mampu mengelola kelas dengan sangat baik. Guru yang belum berhasil mengelolakelas dengan baik diajak berdiskusi setelah supervisi.

5) Menggunakan media pembelajaran, peralatan dan bahan pratikum yang telah ditentukan sebanyak 12 guru berhasil melakukannya dengan baik dengan persentase $63,15 \%$. Banyak guru yang masih jarang menggunakan alat-alat yang bisa menguatkan pembelajaran, khususnya bagi guru kelompok mata pelajaran muatan nasional dan muatan kewilayahan (adaptif dan normatif) dengan alasan mata pelajaran tersebut lebih banyak membahas tentang teori. Tentunya alasan tersebut dikarenakan guru-guru tersebut belum memahami model pembelajaran modern yang sesuai dengan karakteristik pembelajaran abad 21.

6) Menggunakan sumber belajar yang telah dipilih (berupa modul, buku, diktat, program komputer, lembar kerja peserta didik, dan sejenisnya) terdapat 13 guru yang berhasil melakukannya dengan baik dengan persentase 68,42\%. Berdasarkan persentase tersebut maka peneliti masih perlu melakukan bimbingan terhadap guru dalam menentukan dan menggunakan sumber belajar yang sesuai dengan materi ajar.

7) Memotivasi peserta didik dengan berbagai cara yang positif terdapat 16 guru yang melakukannya dengan baik dengan persentase $84,21 \%$. Sebagian besar guru dapat memberikan motivasi kepada peserta didik, yang masih jarang melakukan rata-rata merupakan guru senior yang berusia lima puluh tahun ke atas. Hal ini terjadi karena guru-guru senior tersebut masih terpengaruh pada penerapan model pendidikan lama yang 
berorientasi pada guru. Guru-guru tersebut perlu dia0jak berdiskusi tentang kelebihan dari pemberian motivasi kepada peserta didik.

8) Melakukan interaksi dengan peserta didik menggunakan bahasa yang komunikatif berjumlah 16 guru dengan persentase $84,21 \%$. Guru yang belum dapat berinteraksi secara komunikatif dengan peserta didik, dikarenakan karakter guru tersebut yang cenderung tertutup dan pendiam, dan juga dikarenakan ada guru yang masih baru atau junior.

9) Memberikan pertanyaan dan umpan balik, untuk mengetahui penerimaan peserta didik dalam proses belajar mengajar, terdapat sejumlah 12 guru dengan persentase 63,15\%. Peneliti menemui bahwa masih jarang guru yang memberi umpan balik kepada peserta didik. Rata-rata peserta didik hanya diminta untuk mengerjakan soalsoal yang terdapat pada buku Lembar Kerja Peserta didik (LKS) sampai berakhirnya waktu pembelajaran. Untuk mengatasi hal tersebut, peneliti meminta kepada guru untuk merencanakan penyajian materi dengan memperhatikan ketersediaan waktu yang digunakan

10) Membuat kesimpulan pembelajaran sebanyak 12 guru yang berhasil melakukan dengan baik dengan persentase $63,15 \%$. Masih banyak guru yang tidak membuat kesimpulan pada akhir pembelajaran. Hal ini terjadi karena waktu yang tersedia habis digunakan peserta didik untuk hanya mengerjakan buku LKS. Untuk itu perlu mengarahkan guru untuk membuat kesimpulan sebelum jam pelajaran berakhir.

11) Menggunakan waktu secara efektif dan efisien berjumlah 12 guru dengan persentase $63,15 \%$. Guru masih kurang efektif dalam menggunakan waktu pembeljaran yang ada jika dikaitkan dengan langkah-langkah yang terdapat dalam indikator tersebut, karena waktu peserta didik sangat banyak tersita untuk mengerjakan LKS saja. Untuk itu peneliti perlu membimbing guru untuk merencanakan waktu dengan lebih efektif dan efisien. c. Penilaian Hasil Belajar Peserta Didik Siklus I Hasil refleksi supervisi penilaian hasil belajar pada siklus I setelah diadakan diskusi dengan guru tersebut adalah sebagai berikut:

1) Menyusun atau mengembangkan instrumen penilaian sesuai dengan indikator atau kriteria unjuk kerja pada kompetensi dasar tertentu yang telah ditentukan, terdapat 16 guru dengan persentase $84,21 \%$. Masih terdapat 3 orang guru yang belum mampu membuat instrumen penilaian karena belum sesuai dengan indikator yang dijabarkan pada perangkat pembelajaran yang dibuat. Berdasarkan pengamatan dan analisis ternyata guruguru tersebut belum memahami dengan baik cara menentukan indikator dan penggunaan kata kerja yang ada dalam indikator yang benar berdasarkan kompetensi dasar yang ada. Oleh sebab itu, guru-guru tersebut masih perlu lebih banyak belajar dan memahami bagaimana mendefinisikan indikator yang benar dan memilih kata kerja yang tepat dalam penentuan indikator yang baik dan benar.

2) Melaksanakan penilaian hasil belajar peserta didik, berjumlah 16 guru dengan persentase $84,21 \%$ yang berhasil melakukan dengan baik. Masih ada guru yang membiarkan atau acuh-tak acuh terhadap peserta didik yang membuka buku atau menyontek selama ulangan berlangsung. Hal seperti ini terksesa tidak peduli karena guru hanya menginginkan hasil yang diperoleh peserta didik, namun justru merugikan peserta didik tersebut dan membiarkan karakter peserta didik y ang buruk dan tidak jujur. Bahkan penilaian yang dilakukan dapat dikatakan tidak dapat digunakan untuk mengukur kemampuan peserta didik yang sebenarnya. Guru seperti ini perlu dibimbing secara khusus tentang pentingnya melakukan penilaian yang baik dengan proses yang jujur.

3) Memeriksa jawaban dan memberikan skor tes hasil belajar berdasarkan pedoman penilaian yang telah ditentukan, berjumlah 13 guru dengan persentase $68,42 \%$. Guru yang belum mampu memberikan skor adalah guru yang belum pernah mengikuti pelatihan 
penyusunan rencana pembelajaran dan penyusunan instrumen penilaian. Guruguru tersebut menganggap skor soal sama dengan bobot soal. Untuk mengatasi hal tersebut, guru-guru tersebut diminta untuk mengikuti workshop penyusunan rencana pembelajaran dan penyusunan instrumen penilaian melalui kegiatan MGMP atau diberi bimbingan secara khusus.

4) Melakukan penilaian hasil belajar peserta didik, sejumlah 19 guru atau semua guru dapat melakukan dengan baik dengan persentase 100\%. Karena semua guru sudah mampu melakukan penilaian hasil belajar peserta didik dengan baik, maka kondisi pada indikator ini harus dipertahankan.

5) Mengolah hasil belajar peserta didik terdapat 13 guru yang berhasil melakukan dengan baik dengan persentase $68,42 \%$. Guru yang belum mampu mengolah hasil belajar peserta didik sebagian besar sama dengan guru yang belum paham terhadap penyekoran dan pembobotan nilai.

6) Melakukan analisis penilaian hasil belajar peserta didik (berdasarkan tingkat kesukaran, daya pembeda, validitas, dan reabilitas) berjumlah 13 orang yang berhasil melakukan dengan baik dengan persentase $68,42 \%$. Guru yang tidak mampu melakukan analisis soal rata-rata adalah guru yang enggan menganalisis atau tidak mau menganalisis sehingga lupa bahkan tidak tahu cara menganalisis. Untuk mengatasi hal tersebut, guru-guru tersebut diajak diskusi atau diikutsertakan dalam kegiatan workshop penyusunan rencana

7) Menyimpulkan hasil belajar peserta didik secara jelas dan logis, misalnya interpretasi kecenderungan hasil penilaian, tingkat pencapaian peserta didik, dan lain-lain. Terdapat 13 guru yang dapat melakukan dengan baik dengan persentase $68,42 \%$. Karena tidak dapat melakukan analisis butir soal, akibatnya guru tersebut tidak bisa menyimpulkan penilaian penilaian secara logis dan jelas. Untuk mengatasi hal tersebut, maka guru-guru tersebut diajak berdiskusi atau diikutsertakan dalam kegiatan workshop penyusunan rencana pembelajaran dan penyusunan instrumen penilaian di sekolah.

8) Menyusun laporan hasil belajar peserta didik, semua guru telah berhasil melaksanakan indikator ini dengan baik dengan persentase $100 \%$.

9) Memperbaiki soal atau instrumen penilaian sejumlah 19 guru atau semua guru telah berhasil melaksanakan indikator ini dengan baik dengan persentase $100 \%$.

d. Pelaksanaan Tindak Lanjut Hasil Penilaian Siklus I

1) Mengidentifikasi kebutuhan tindak lanjut hasil penilaian berjumlah 13 guru dengan persentase $68,42 \%$. Pada bagian ini masih banyak guru yang belum mampu mengidentifikasikan kebutuhan tindak lanjut. Oleh sebab itum pada siklus berikutnya (siklus II) guru tersebut diajak berdiskusi tentang pentingnya pelaksanaan tindak lanjut tersebut

2) Menyusun program tindak lanjut hasil penilain, terdapat 16 guru yang berhasil melakukan dengan baik dengan persentase $84,21 \%$. Guru yang belum mampu menyusun program tindak lanjut perlu diikusertakan dalam workshop atau dibimbing oleh peneliti dalam penyusunan program tindak lanjut.

3) Melaksanakan tindak lanjut sejumlah 9 guru berhasil melakukan dengan baik dengan persentase $47,36 \%$. Karena masih banyak guru yang belum melaksanakan tindak lanjut hasil penilaian, maka peneliti perlu memberikan motivasi dan binmbingan seacara terus menerus kepada guruguru tersebut supaya melaksanakan tindak lanjut hasil penilaian.

4) Melakukan evaluasi hasil tindak lanjut hasil penilaian, sejumlah 9 guru berhasil melakukan dengan baik dengan persentase $47,36 \%$. Hal ini karena guruguru tersebut belum melaksanakan tindak lanjut hasil penilaian, sehingga tentunya tidak dapat melakukan evaluasi tindak lanjut hasil penilaian tersebut. Untuk itu peneliti perlu memberikan 
motivasi dan binmbingan seacara terus menerus kepada guru-guru tersebut.

5) Menganalisa hasil evaluasi program tindak lanut hasil penelitian, sejumlah 9 guru berhasil melakukan dengan baik dengan persentase 47,36\%. Hasil analisis yang dilakukan oleh guru masih sedikit, dan yang tidak melakukan analisis hasil evaluasi program tindak lanjut adalah guru-guru yang tidak melaksanakan evaluasi hasil tindak lanjut hasil penilaian. Untuk itu peneliti perlu memberikan motivasi dan bimbingan seacara terus menerus kepada guru-guru tersebut.

Berdasarkan uraian tentang refleksi hasil pada siklus I, diketahui bahwa rata-rata keberhasilan guru dalam proses pembelajaran secara umum masih dibawah 75 sehingga belum memenuhi indikator keberhasilan yang diinginkan. Untuk itu pada Siklus II dilakukan tahapan yang sama dengan siklus I sebagai perbaikan dari hasil siklus I.

\section{Siklus II}

Berdasarkan data yang disajikan pada tabel 5 sampai dengan tabel 8, dapat dijelaskan sebagai berikut:

a. Perencanaan Pembelajaran Siklus II

Setelah peneliti melakukan diskusi dengan guru yang disupervisi, maka hasil refleksi supervisi perencanaan pembelajaran siklus II adalah sebagai berikut:

1) Merumuskan indikator pencapaian kompetensi sesuai dengan kompetensi dasar pada mata pelajaran tersebut. Pada bagian ini terdapat 18 guru yang sudah berhasil melakukan dengan baik dengan persentase 94,73\%. Berdasarkan data tersebut dapat dikatakan bahwa hampir semua guru sudah mampu merumuskan indikator pencapaian kompetensi berdasarkan kompetensi dasar yang ada. Walaupun masih terdapat seorang guru yang belum melakukannya dengan baik, namun hasil ini patut dipertahankan. Dan untuk guru yang belum dapat melaksanakannya dapat dilakukan bimbingan oleh peneliti maupun bersama teman guru dalam kegiatan MGMP.

2) Mendeskripsikan tujuan pembelajaran terdapat 18 guru yang mampu melaksanakannya dengan baik dengan persentase 94,73\%. Hampir semua guru sudah mampu merumuskan tujuan pembelajaran yang benar berdasarkan indikator pencapaian kompetensi yang sudah ditentukan, dan kondisi ini perlu dipertahankan. Walaupun masih terdapat seorang guru yang belum dapat melakukannya dengan baik dan guru tersebut diharapkan untuk tetap belajar bersama dalam kegiatan MGMP serta tetap dibimbing oleh peneliti.

3) Menentukan materi ajar terdapat 18 guru yang berhasil melakukan dengan baik dengan persentase $94,73 \%$. Dapat dilihat bahwa hampir semua guru mampu menentukan materi ajar yang memuat fakta, konsep, prinsip dan prosedur yang relevan, dan ditulis dalam bentuk butir-butir pokok bahasan/sub pokok bahasan sesuai dengan rumusan indikator pencapaian kompetensi yang dibuat. Guru yang belum mampu melakukannya dengan baik, ke depannya tetap dibimbing dan diberi motivasi oleh peneliti.

4) Mengorganisasikan materi sesuai langkah-langkah kegiatan pembelajaran. Pada bagian ini terdapat 16 guru yang berhasil melakukan dengan baik dengan persentase $84,21 \%$. Walaupun masih terdapat 3 guru yang belum melakukan dengan baik, namun kondisi ini perlu dipertahankan. Dan ketiga guru tersebut dapat terus belajar dari guru-guru yang sudah mampu dan tetap perlu dibimbing dan diberi motivasi oleh peneliti.

5) Mengalokasikan waktu semua guru (19 guru) telah mampu melakukannya dengan baik dengan persentase $100 \%$. Kondisi ini sangat baik dimana semua guru telah mampu mengalokasikan waktu pembelajaran sesuai dengan materi yang diberikan dan tujuan pembelajaran yang hendak dicapai. 
6) Menentukan model pembelajaran, terdapat 18 guru yang dapat melakukannya dengan baik dengan persentase 94,73\%. Walaupun masih terdapat seorang guru yang masih perlu dimotivasi dan dibimbing, namun hampir semua guru mampu menentukan model pembelajaran dengan mempertimbangkan karakteristik peserta didik, dan karakteristik materi pembelajaran, untuk menstimulan kemampuan ketrampilan dan daya karya peserta didik, baik secara individual maupun kelompok. Konsisi ini perlu dipertahankan dan terus ditingkatkan.

7) Membuat atau menentukan media pembelajaran terdapat 16 orang guru yang berhasil melakukan dengan persentase $84,21 \%$. Walaupun media pembelajaran yang dikembangkan masih dikategorikan sederhana, namun keinginan guruguru untuk membuat sendiri media pembelajaran yang kreatif dan inovatif sebagai alat bantu guru untuk menyampaikan materi pembelajaran, agar peserta didik termotivasi, menarik perhatian, dan berminat mengikuti pelajaran, sangat peneliti apresiasi. Guru-guru yang belum berhasil, walaupun belum membuat media pembelajaran sendiri, namun sudah mampu memanfaatkan media pembelajaran instan (buatan orang lain) sesuai dengan materi ajar yang diampu.

8) Menentukan sumber belajar 19 guru dengan persentase 100\%. Dari angka tersebut berarti semua guru sudah mampu menentukan sumber belajar yang tepat, sesuai dan relevan dengan materi ajar dan kompetensi dasar. Seumber belajar dapat berupa buku cetak, buku elektronik, media informasi yang berfungsi sebagai sumber belajar, peralatan, dan lingkungan yang relevan.

9) Merancang langkah-langkah kegiatan pembelajaran terdapat 18 orang guru dengan persentase $94,73 \%$. Hampir semua guru mampup merancang langkahlangkah kegiatan pemebelajaran yang baik dan runtut, sebagai aktifitas pengelolaan pengalaman belajar peserta didik, melalui tahapan pendahuluan, inti, dan penutup. Untuk guru yang belum berhasil melakukan dapat belajar dari guru yang sudah mampu dan tetap diberi motivasi dan bimbingan oleh peneliti.

10) Menentukan teknik penilaian dan mengembangkan instrumen penilaian terdapat 16 guru dengan persentase $84,21 \%$. Kondisi ini perlu dipertahankan dan ditingkatkan. Bagi guru yang belum dapat mengembangkan perangkat penilaian yang baik, dapat belajar dan didampingi oleh guru yang sudah mampu dan peneliti.

\section{b. Pelaksanaan Pembelajaran Siklus II}

Hasil refleksi pada kegiatan supervisi pelaksanaan pembelajaran siklus II adalah sebagai berikut:

1) Membuka pelajaran menggunakan metode yang sesuai terdapat 19 guru yang berhasil melakukan dengan sangat baik dengan persentase $100 \%$. Semua guru yang disupervisi dapat membuka pelajaran dengan baik dan tepat waktu. Kondisi ini perlu dipertahankan dan terus ditingkatkan.

2) Melakukan apersepsi dan memberi motivasi kepada peserta didik sebanyak 18 guru berhasil melakukan dengan baik dengan persentase $94,73 \%$. Masih terdapat seorang guru yang belum melakukan dengan baik karena belum memahami bagaimana melakukan apersepsi terhadap peserta didik. Guru ini perlu dimotivasi dan belajar dari guru-guru yang sudah mampu.

3) Menyajikan materi ajar sebanyak 17 guru yang berhasil melakukan dengan baik dengan persentase $89,47 \%$. Kondisi ini perlu dipertahankan, walaupun masih terdapat 2 guru yang belum melakukan dengan baik, hal ini dikarenakan guru-guru tersebut 
belum menguasai materi baru yang dituntut oleh kurikulum 2013 dengan baik. Guru-guru tersebut perlu diberi motivasi untuk tetap up to date terhadap perkembangan materi ajar sesuai dengan tuntutan kurikulum yang berlaku.

4) Menerapkan model pembelajaran sebanyak 16 guru dengan persentase $84,21 \%$. Berdasasrkan data tersebut diketahui bahwa sebagian besar guru telah memahami model pembelajaran yang berorientasi pada peserta didik dan mampu menerapkannya sesuai dengan karakteristik peserta didik dan karakteristik materi ajar yang diampu. Guru yang belum berhasil melakukan dikarenakan belum memahami dengan baik model pembelajaran modern sesuai dengan tuntutan pembelajaran abad 21 . Guru-guru tersebut disarankan untuk lebih banyak belajar dari guru senior dan yang sudah mampu atau mengikuti pelatihan terkait dengan model pembelajaran modern.

5) Melaksanakan pembelajaran sesuai dengan langkah-langkah pembelajaran yang benar dan tertuang dalam RPP sebanyak 18 guru dengan persentase $94,73 \%$. Kondisi ini perlu dipertahankan walaupun masih terdapat seorang guru yang perlu diberi motivasi dan disarankan untuk belajar dari guru senior atau guru yang sudah mampu.

6) Mengatur kegiatan peserta didik di kelas sesuai dengan tahapantahapan pembelajaran yang tertuang dalam RPP sebanyak 18 guru dengan persentase $94,73 \%$ berhasil melakukan dengan baik. Dari data tersebut 1 guru yang belum melakukan dengan baik karena faktor peserta didik maupun pendekatan guru terhadap peserta didik yang kurang efektif.

7) Menggunakan media pembelajaran terdapat 16 guru yang berhasil melakukan dengan baik dengan persentase $84,21 \%$. Sebagian besar guru mampu membuat dan mengembangkan media pembelajaran secara mandiri sendiri sesuai dengan materi ajar dan tertuang di dalam RPP. Untuk guru yang belum membuat media secara mandiri dan masih menggunakan media buatan orang lain, disarankan untuk belajar lebih banyak dari guruguru yang mampu dan mengikuti pelatihan pembuatan media belajar interaktif dan kreatif.

8) Menggunakan sumber belajar sebanyak 19 guru dengan persentase $100 \%$. Data ini menunjukkan bahwa semua guru mampu menentukan dan menggunakan sumber belajar yang telah dipilih dan tertuang dalam RPP sesuai dengan materi ajar yang diberikan.

9) Melakukan interaksi dengan peserta didik menggunakan bahasa yang komunikatif sebanyak 19 guru dengan persentase $100 \%$. Berdasarkan data tersebut, diketahui bahwa semua guru dapat berkomunikasi dengan peserta didik menggunakan bahasasehari-hari secara komunikatif.

10) Memberikan pertanyaan dan umpan balik sebanyak 17 guru dengan persentase $89,47 \%$. Kondisi ini perlu dipertahankan, dimana hampir semua guru mampu memberikan pertanyaan-pertanyaan sebagai umpan balik. Hal ini dikarenakan ada kerjasama antara guru dengan peneliti.

11) Bersama peserta didik menyimpulkan pembelajaran sejumlah 18 guru dengan persentase $94,73 \%$ berhasil melakukan dengan baik. Setelah pelaksanaan siklus I, peneliti melakukan diskusi secara intensif dengan guru-guru yang disupervisi tentang cara menyimpulkan pembelajaran. Hasil diskusi, motivasi dan masukan dari peneliti kepada guru tersebut ternyata memberikan hasil yang memuaskan, dimana hampir semua guru mampu menyimpulkan pembelajaran. Walaupun terdapat seorang guru yang belum maksimal dalam indikator ini dan masih perlu diberi motivasi, namun kondisi ini 
perlu dipertahankan dan ditingkatkan.

12) Menggunakan waktu secara efektif dan efisien sebanyak 19 guru dengan persentase $100 \%$. Pada siklus II ternyata semua guru berhasil memanfaatkan waktu pembelajaran dengan efektif sesuai alokasi waktu yang ada.

c. Penilaian Hasil Belajar Peserta Didik Siklus II

Hasil refleksi pada supervisi penilaian hasil belajar siklus II adalah sebagai berikut:

1) Menyusun instrumen penilaian sebanyak 18 guru dengan persentasae $94,73 \%$. Masih terdapat satu orang guru yang belum mampu menyusun instrumen penilaian dengan baik karena tidak sesuai dengan indikator yang telah ditentukan. Berdasarkan pengamatan ternyata guru tersebut pada pertemuan dengan peneliti tidak masuk karena sakit. Guru tersebut perlu belajar dari guru yang sudah mampu untuk dapat menyusun instrumen penilaian sesuai dengan kompetensi dasar yang akan diukur, materi ajar yang diberikan, dan indikator yang mengacu pada kompetensi dasar. Mulai dari kisi-kisi, butir soal, kunci jawab, rubrik penilaian, dan pedoman penskoran.

2) Melaksanakan kegiatan penilaian hasil belajar sebanyak 18 guru dengan persentase $94,73 \%$. Hampir semua guru mampu melaksanakan penilaian sesuai dengan aturan, dimana peserta didik terkondisi tertib, tidak menyontek, tidak bertanya pada peserta didik lain selama proses penilaian berlangsung. Hal seperti ini perlu dipertahankan sehingga pelaksanaan penilaian benar-benar dapat mengukur kemampuan peserta didik secara jujur.

3) Memeriksa hasil tes sebanyak 18 guru dengan persentase 94,73\% berhasil melakukan dengan baik.
Guru sudah dapat membedakan antara bobot soal dan skor sehingga hampir semua guru mampu memberikan skor berdasarkan kunci jawab, rubrik penilaian, dan pedoman penskoran yang telah ditentukan.

4) Mengolah hasil penilaian sebanyak 19 guru dengan persentase $100 \%$. Semua guru sudah mampu mengolah nilai mulai dari penskoran, pembobotan, sampai dengan pengolahan nilai akhir. Hal ini perlu dipertahankan.

5) Menganalisis hasil penilaian berdasarkan tingkat kesukaran, daya pembeda, validitas, dan reabilitas) sebanyak 17 guru dengan persentase $89,47 \%$. Hampir semua guru sudah berhasil melakukan analisis hasil penilaian. Terdapat 2 guru yang belum berhasil, dikarenakan guru tersebut enggan atau tidak mau menganalisis hasil penilaian sehingga beralasan lupa cara menganalisis. Menghadapi masalah ini, peneliti perlu berdiskusi dengan guru yang belum mampu dan memotivasi guru untuk belajar dari guru yang sudah mampu atau narasumber lain yang kompeten.

6) Menyimpulkan hasil penilaian secara jelas dan logis sebanyak 17 guru dengan persentase $89,47 \%$ berhasil melakukan dengan baik.

7) Menyusun laporan hasil penilaian sebanyak 19 guru dengan persetase $100 \%$. Kondisi ini perlu dipertahankan karena semua guru yang disupervisi mampu menyusun laporan hasil penilaian yang lengkap.

8) Memperbaiki perangkat penilaian sejumlah 16 guru dengan persentase $84,21 \%$. Kondisi ini sudah sangat baik, walaupun masih terdapat 3 guru yang belum berhasil, karena menilai bahwa soal yang sudah dibuat tidak perlu diperbaiki. Pada dasarnya hal tersebut dikarenakan guru yang belum berhasil tersebut malas memperbaiki perangkat yang sudah dibuat.

d. Tindak Lanjut Hasil Penilaian Siklus II 
Refleksi pada bagian tindak lanjut ini dilakukan berdasarkan data yang telah dikumpulkan sebagai berikut:

1) Mengidentifikasi kebutuhan tindak lanjut hasil penilaian sejumlah 16 guru dengan persentase $84,21 \%$. Data ini dapat dikatakan bahwa pada siklus II perkembangan guru cukup pesat, walaupun masih terdapat 3 guru yang belum melakukan indentifikasi kebutuhan tindak lanjut. Untuk itu kondisi ini perlu dipertahankan.

2) Menyusun program tindak lanjut hasil penilaian sebanyak 16 guru dengan persentase $84,21 \%$. Dengan dilakukannya supervisi edukatif kolaboratif, ternyata banyak guru yang sebelumnya belum dapat menyusun program tindak lanjut, ternyata pada siklus II berhasil menyusun dengan baik dengan skor total lebih dari 80. Untuk itu model ini perlu dipertahankan oleh sekolah.

3) Melaksanakan tindak lanjut sebanyak 16 guru dengan persentase $84,21 \%$. Berdasarkan data tersebut guru SMK Negeri 1 Kademangan yang disupervisi sudah banyak yang mampu melaksanakan tindak lanjut hasil penilaian. Walaupun masih terdapat 3 guru yang memperoleh skor pelaksanaan tindak lanjut di bawah 80.

4) Mengevaluasi hasil tindak lanjut hasil penilaian sebanyak 16 guru dengan persentase $84,21 \%$. Dengan persentase tersebut dapat dikatakan bahwa pada siklus II ini sudah banyak guru yang memapu mengevaluasi hasil tindak lanjut, dan perlu dipertahankan.

5) Menganalisis hasil evaluasi program tindak lanjut hasil penilaian sebanyak 16 guru dengan persentase $84,21 \%$. Hampir semua guru sudah menganalisis hasil evaluasi program tindak lanjut hasil penilaian walaupun masih ada guru yang hasil analisisnya masih kurang memadai

Berdasarkan uraian hasil penelitian di atas, peneliti menghentikan penelitian tindakan ini sampai pada siklus II, karena hasil yang diperoleh pada siklus II yang merupakan tindak lanjut dari hasil refleksi pada siklus I, sudah sangat memuaskan. Keberhasilan tindakan pada siklus II mengalami peningkatan yang cukup signifikan dibandingkan pada siklus I, yang digambarkan dalam Grafik 3 berikut ini:

Grafik 3. Perbandingan Keberhasilan Siklus I dengan Siklus II

\section{Perbandingan Keberhasilan Siklus I dengan Siklus II}

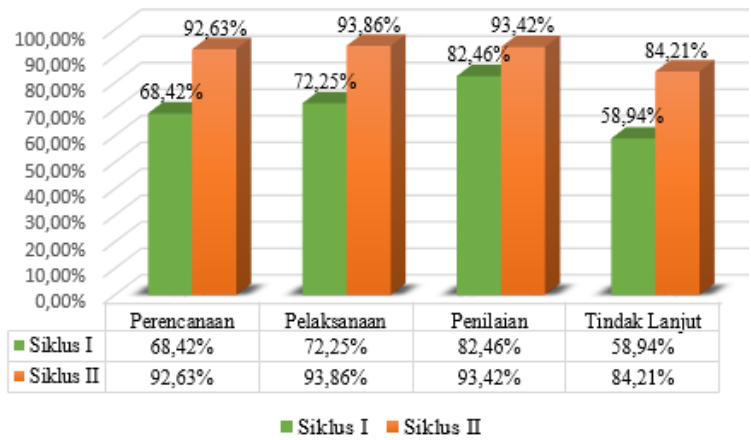

Berdasarkan hasil penelitian tindakan yang telah dilakukan oleh peneliti mulai dari tahap pra siklus, siklus I, sampai dengan siklus II yang diperoleh dan telah diuraikan secara rinci, maka pembahasan hasil penelitian tindakan yang dapat disampaikan oleh peneliti adalah sebagai berikut:

1) Temuan pertama, kinerja guru SMK

Negeri 1 Kademangan yang disupervisi meningkat dalam pembuatan dan penyusunan perencanaan dan perangkat pembelajaran. Hal ini terjadi karena adanya kerjasama antar sesama guru, guru yang sudah mampu dengan yang belum mampu, guru mata pelajaran dalam satu MGMP, dan pengarahan dan bimbingan yang dilakukan oleh peneliti sebagai kepala sekolah.

2) Temuan kedua, kinerja guru meningkat dalam pelaksanaan pembelajaran di dalam kelas. Pada dasarnya seorang guru merupakan orang yang mampu mengajar, namun belum tentu semua guru dapat melaksanakan pembelajaran yang kreatif, menyenangkan, dan berorientasi pada peserta didik. Dalam penelitian tindakan ini awalnya hanya $72,25 \%$ guru yang dapat melaksanakan pembelajaran yang menyenangkan dan interaktif, walaupun suasana dan kondisi kelas masih agak canggung karena 
peneliti turut serta dalam proses belajar mengajar di dalam kelas. Namun selanjutnya pada pelaksanaan pembelajaran di siklus II, persentase keberhasilan guru dalam melaksanakan pembelajaran yang kreatif, menyenangkan, dan berorientasi pada peserta didik meningkat sebesar $21,31 \%$ menjadi $93,86 \%$. Perolehan persentase tersebut menunjukkan bahwa terjadi peningkatan kinerja guru dalam pelaksanaan pembelajaran.

3) Temuan ketiga, kinerja guru meningkat dalam menilai hasil belajar peserta didik. Pada penelitian tindakan yang dilakukan di SMK Negeri 1 Kademangan, hasil yang diperoleh menunjukkan bahwa pelaksanaan supervisi edukatif kolaboratif secara periodik memberikan dampak yang positif terhadap guru dalam penyusunan dan pembuatan instrumen penilaian, pelaksanaan penilaian, pengolahan hasil penilaian, analisis hasil penilaian, dan tindak lanjut hasil penilaian. Pada awal pelaksanaan supervisi edukatif kolaboratif ini, masih banyak guru yang mengalami kesulitan dalam proses penilaian hasil belajar peserta didik. Walaupun persentase penilaian di awal menunjukkan hasil yang baik yaitu $82,46 \%$, namun belum semua guru melaksanakan penilaian yang menyeluruh. Persentase tersebut merupakan hasil penilaian guru dengan pengukuran hasil belajar siswa yang belum maksimal, dimana soal yang dibuat masih memiliki analisis kemampuan yang rendah, siswa hanya dinilai berdasarkan hasil bukan proses, sehingga banyak siswa dengan nilai yang tinggi namun bukan hasil pekerjaan sendiri. Namun setelah peneliti bersama guru berdiskusi secara terus menerus untuk membuat instrumen penilaian, melaksanakan penilaian menggunakan model penilaian otentik, secara terus menerus, maka pada siklus II dapat diperoleh persentase

\section{KESIMPULAN}

Pelaksanaan supervisi edukatif kolaboratif yang dilakukan dapat meningkatkatkan kinerja guru, meningkatkan kualitas pembelajaran yang berpengaruh pada hasil belajar peserta didik yang juga meningkat, dan terjalin hubungan sebesar 93,42\%. Hasil tersebut baik sebesar 10,96\% dengan kualitas pengukuran yang lebih komperhensif berdasarkan kemampuan peserta didik secar menyeluruh mulai dari penilaian sikap, pengetahuan, dan ketrampilan.

4) Temuan keempat, kinerja guru dalam melaksanakan tindak lanjut hasil penilaian hasil belajar peserta didik meningkat setelah pelaksanaan supervisi edukatif kolaboratif.

Dari temuan-temuan tersebut dapat dilihat bahwa pelaksanaan supervisi edukatif kolaboratif yang dilakukan oleh peneliti dapat meningkatkan kinerja guru dalam perencanaan (penyusunan perangkat pembelajaran), pelaksanaan pembelajaran, penilaian hasil belajar, dan tindak lanjut hasil penilaian hasil belajar. Peningkatan tersebut dapat dilihat pada Grafik 4, yang menunjukkan kenaikan yang signifikan dari siklus I ke siklus II untuk empat komponen kinerja guru yang disupervisi.

Grafik 4. Persentase Kenaikan Hasil Kinerja Guru Siklus I dengan Siklus II

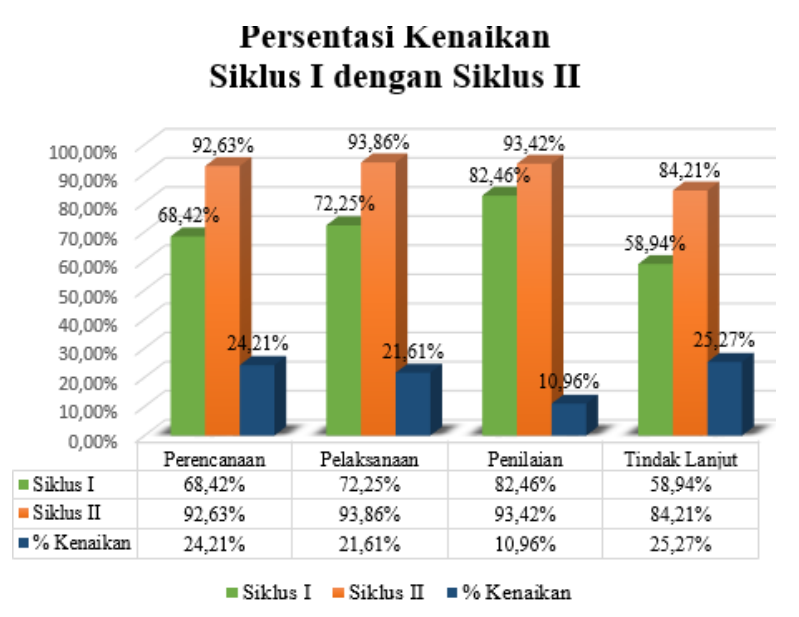

yang kooperatif dan kolegial antara peneliti sebagai supervisor/kepala sekolah dan guru SMK Negeri 1 Kademangan.

\section{SARAN}


Berdasarkan kesimpulan, ada beberapa saran yang perlu disampaikan sebagai bahan pertimbangan dan perhatian semua pihak, yaitu:

1. Supervisi terhadap guru perlu dilakukan sebagai bentuk pembinaan terhadap guru dalam meningkatkan kemampuan untuk mengembangkan situasi belajar mengajar yang lebih baik. Pelaksanaan supervisi sebaiknya menggunakan metode dan pendekatan yang bersahabat, edukatif, dan kolaboratif sehingga guru yang disupervisi tidak merasa tertekan selama proses supervisi berlangsung.

2. Supervisi edukatif yang dilakukan secara kolaboratif perlu dilaksanakan secara periodik dan berkesinambungan sehingga kinerja guru dapat ditingkatkan dan dipertahankan, yang juga tentunya dapat meningkatkan hasil belajar peserta didik.

3. Supervisi edukatif kolaboratif yang melibatkan teman sejawat yang sudah mampu pada mata pelajaran tersebut, akan memberikan motivasi dan efek yang lebih baik terhadap guru yang disupervisi dalam peningkatan kinerja guru.

\section{DAFTAR RUJUKAN}

Bazrafkan, L., Yousefy, A., Amini, M., \& Yamani, N. (2019). The journey of thesis supervisors from novice to expert : a grounded theory study. 1-12.

Bouchamma, Y. (2007). Evaluating Teaching Personnel. Which Model of Supervision Do Canadian Teachers Prefer? (2005), 289-308.

https://doi.org/10.1007/s11092-0079025-8

Departemen Pendidikan Nasional, 2003. Undang-undang Nomor Tahun 2003 tentang Sistem Pendidikan Nasional. Jakarta: Depdiknas.

Direktorat Pembinaan Sekolah Menengah Atas Kementerian Pendidikan dan Kebudayaan. 2017. Panduan Supervisi Akademik. Jakarta: Dirjen Dikdasmen.

Ellett, C. D., \& Teddlie, C. (2003). Teacher Evaluation, Teacher Effectiveness and School Effectiveness: Perspectives from the USA. 101-128.

Jaffer, K. (2010). School inspection and supervision in Pakistan: Approaches and issues. (March 2009), 375-392. https://doi.org/10.1007/s11125-0109163-5

Kalule, L., \& Bouchamma, Y. (2014). Teacher supervision practices and characteristics of in-school supervisors in Uganda. 51-72.

https://doi.org/10.1007/s11092-0139181-y

Lavigne, A. L., \& Chamberlain, R. W. (2017). Teacher evaluation in Illinois: school leaders 'perceptions and practices. 179-209. https://doi.org/10.1007/s11092-0169250-0

Liu, K., Miller, R., Dickmann, E., \& Monday, K. (2018). Virtual Supervision of Student Teachers as a Catalyst of Change for Educational Equity in Rural Areas. 8-19.

Lynne, M., \& John, D. (2015). Implementing new teacher evaluation systems : Principals ' concerns and supervisor support. Journal of Educational Change, 305-326. https://doi.org/10.1007/s10833-0159244-6

Range, B. G., Scherz, S., Holt, C. R., \& Young, S. (2011). Supervision and evaluation: The Wyoming perspective. 243-265. https://doi.org/10.1007/s11092-0119123-5

Undang-undang Republik Indonesia Nomor 14 tentang Guru dan Dosen. 2005. Jakarta: Deputi Mensesneg Bidang Perundang-undangan.

Undang-undang Republik Indonesia Nomor 2 tentang Sistem Pendidikan Nasional. 1990. Jakarta: PT Armas Duta Jaya. 